\title{
HEPATIC AND NEURAL TOXICITY AND TISSUE RESIDUE OF CYPERMETHRIN IN MALE SOMALI SHEEP (BERBERA BLACKHEAD)
}

\author{
ADEL G. EL-SHEMI ${ }^{* * * *}$ and GHADA A. ABOU EL-ELLA ${ }^{* * * * *}$ \\ * Department of Laboratory Medicine, Faculty of Applied Medical Sciences, Umm Al-Qura University, Saudi Arabia. \\ ** Department of Pharmacology, Faculty of Medicine, Assiut University, Egypt. \\ *** Clinical Laboratory diagnosis, Department of Animal Medicine, Faculty of Veterinary Medicine, Assiut University, \\ Egypt.
}

Email: ghadaabou22@yahoo.com

Assiut University web-site: www.aun.edu.eg

Received at: 31/5/2015

Accepted: 29/6/2015

\section{ABSTRACT}

The effect of type II synthetic pyrethroid, cypermethrin on selected physiological and biochemical parameters of liver and neural system were studied in male Somali sheep. In addition, the residue of cypermethrin in different tissues and body execreta were also evaluated. Two tested doses (6 and $12 \mathrm{mg} / \mathrm{kg} \mathrm{b}$.wt/day) of cypermethrin were given orally to sheep for 63 consecutive days. A vehicle-control group of sheep given corn oil $(0.1 \mathrm{ml} / \mathrm{kg} /$ day $)$ only was used for comparison. Investigated animals of all groups were slaughtered $24 \mathrm{~h}$ after the last dose. No fatality was recorded during the course of this study. Cypermethrin produced significant increase in the weights of liver and spleen, while there were no effects on the weights of brain, kidneys, heart and testes. A significant increase in liver aspartate amino transaminase (AST) and alanine amino transaminase (ALT) activities and a significant decrease in liver lactate dehydrogenase (LDH) activity were recorded in the pesticide-treated animals. Significant decreases were observed in brain $\mathrm{Na}^{+}, \mathrm{K}^{+}$-ATPase and $\mathrm{Mg}^{++}$-ATPase in cypermethrin-treated animals that were dose-dependant. Residue analysis revealed higher levels of cypermethrin in spleen, kidneys and muscle than liver. Residues of tested pesticide were detected in all samples of urine and faeces of treated sheep, and were dose-dependent. From this study it can be concluded that exposure of farm animals for long periods to cypermethrin pesticide will affect their physiological and biochemical parameters with subsequent adverse effect on animal health and production. Moreover, the presence of large amount of tissue residues of this compound in animal tissues and excreta could affect human health as well. Therefore, farm animals should not exposed to theses pesticide for long times via food or water.

Key words: Cypermethrin, hepatic toxicity, neural toxicity, tissue residues, Somali sheep

\section{INTRODUCTION}

Pesticides constitute the major source of potential environmental hazards not only for animals but also to human when they become part of food chains (Abd-Alla et al., 2002). Various chemicals have been used as pesticides in public health programs, veterinary and agriculture. Greater reliance on the use of pesticides to maintain higher agricultural productivity appears inevitable as the demand for food increases with increasing population (Abou Zeid et al., 1993). Intensive agriculture activities require the application of large quantities of pesticides annually. The long term application of these pesticides is always expected to induce pesticide residues accumulation in soil, water, and in the general environment, thereby posing a serious threat to public health (El-Sebae, 1990; Abdul Mujeeb and Shakoori, 2007). It is believed that numerous undocumented cases of acute poisoning to human, farm animals, honey bees, and fish, due to direct dermal contact or ingestion of contaminated food and water occur annually (Abdul Mujeeb and Shakoori, 2007).

Synthetic pyrethroid is one of the main classes of insecticides widely used in agriculture. Pyrethroids are preferred above organophosphates, carbamates and organochlorines as these have high efficiency, low toxicity and easy biodegradability (Sharaf et al., 2010). For more than 30 years, pyrethroids are in use for home formulations and agricultural purposes and 
these insecticides cover nearly one-fourth of the worldwide market (Ahmad et al., 2012). In spite of claims of low mammalian toxicity of pyrethroid, evidence is gradually accumulated against it as several reports descriped and documented the toxicological effects of various pyrethroid insecticides in many species of animals (Shakoori et al., 1988; Moore and Waring, 2001; Abdul Mujeeb and Shakoori, 2007; Khan et al., 2012). Cypermethrin (CY) (type II synthetic pyrethroid) lipophilic in nature, is considered to be less toxic due to its speedy insect killing properties and having low toxicity to mammalian tissues (Aslam et al., 2010). However, it is fairly toxic when applied dermally or administered orally (Luty et al., 1998 and Aslam et al., 2010). Moreover, it can exert significant adverse effects in non-target species including humans and livestock animals (Baselt, 2008).

The magnitude of toxic effects of pesticides depends mainly on the type and dose of compound, duration of exposure, species and age of animals and other environmental factors (Dunnick et al., 1984). Farm animals have been contaminated in a variety of ways, thus possibly affecting the animal's growth and production. Sheep are usually dipped or treated with insecticides each year in order to prevent and control ectoparasites. Cypermethrin is being increasingly used as the active ingredient in many dips which are used to prevent and treat ticks, lice and scab on sheep (Hardeng et al., 1992 and Khan et al., 2012) Therefore, the current study aimed to investigate the effect of long term exposure to cypermethrin, one of the synthetic pyrethroids, on some hepatic and neural parameters and to determine its tissue residues in male sheep after repeated oral administration.

\section{MATERIALS and METHODS}

\section{Pesticide}

An active type II synthetic pyrethroid insecticide (cypermethrin) was used in the present study. Cypermethrin $[25 \%$ E.C (RS)-alpha-cyano-3phenoxybenzyl (IRS)-cis-, trans-3-(2,2dichlorovinyl)-2,2-dimethyl-cyclopropane

carboxylate] (Mitchell Cotts Chemicals, Belgium). Cypermethrin was prepared in corn oil and were administered orally in gelatin capsules to sheep.

\section{Animals and treatment}

Eighteen male Somali sheep (Berbera Blackhead) aged eight to ten months of $27.5 \pm 2.36 \mathrm{~kg}$ average body weight were used in this study. The animals were housed in shelter and fed on roughage (rice straw) and concentrate supplement according to their actual requirements (NRC, 1985). The concentrate contained at least $61 \%$ total digestible nutrients (TDN) and $11.5 \%$ digestible proteins (DP). Feed and water were provided to animals ad libitum throughout the experiment. The animals were divided into 3 groups of six animals each. The first group was treated orally with corn oil daily at $0.1 \mathrm{ml} / \mathrm{kg}$ for 63 days and kept as vehicle control. The second and third groups were orally treated with cypermethrin at low and high doses of 6 and $12 \mathrm{mg} / \mathrm{kg}$ body weight/day, respectively (Yousef et al., 1998) for 63 successive days. Doses of tested pesticide were formulated weekly to meet the weight changes. The dose for each animal was contained in a gelatin capsule that was inserted orally into the esopharyngeal region with the help of a glass rod. Animals were observed daily for the nature and onset of toxic signs. Body weights were recorded at the beginning of the experiment and every week thereafter. One day after the last treatment, all investigated animals were slaughtered and their liver, kidney, heart, spleen, testis, brain and lung were immediately excised and washed in cold saline. The organs were weighed after blotting them dry and the organ: body weight ratio was calculated.

\section{Biochemical studies}

Freshly removed liver and brain were washed using chilled saline solution and homogenized (10\% w/v) in $0.25 \mathrm{M}$ ice cold sucrose solution in a PotterElvehjem type homogenizer. The homogenates were centrifuged at $700 \mathrm{xg}$ for $10 \mathrm{~min}$. at $4{ }^{\circ} \mathrm{C}$ to remove cell debris. The liver supernatant was used for estimation of aspartate amino transaminase (AST) and alanine amino transaminase (ALT), acid phosphatase (AcP), alkaline phosphatase (AlP) and lactate dehydrogenase (LDH) activities according to Reitman and Frankel (1957); Bergmeyer (1963); Bessey et al. (1964) and Cabaud and Wroblewski (1958), respectively, using commercially available kits (Pasteur Lab, USA). The brain supernatant was used for estimation of acetylcholinesterase (AChE) activity according to Ellman et al. (1961). Brain tissues of sheep were prepared as described by Koch (1969) for determination of $\mathrm{Na}^{+}, \mathrm{K}^{+}$-ATPase and $\mathrm{Mg}^{++}$-ATPase activities. ATPase activities were assayed according to Cutkomp et al. (1971) where inorganic phosphate was determined according to the method of Fiske and Subbarow (1925). Protein in brain ATPase preparations was estimated by the method of Lowry et al. (1951).

\section{Residue analysis}

Samples of urine $(100 \mathrm{ml})$ and faeces $(100 \mathrm{gm})$ were collected once a week and continued throughout the experimental period. Kidney (50 gm), spleen (25 $\mathrm{gm})$, liver (50 gm) and forequarter muscles (100 gm) were collected from the sacrificed animals (control and treated). Levels of cypermethrin in all samples were analysed according to Braun and Stanek (1982), and AOAC (1984), respectively. Gas chromatograph (GC) (Hewlett Packard series 5890) was used. GC equipped with ${ }^{3} \mathrm{H}$-electron capture detector (ECD) to 
detect cypermethrin. Megabore column HP-608 part No. 190955-023; (30 m x $0.53 \mathrm{~mm}$ i.d x $0.5 \mu \mathrm{m}$ film thickness) was used. Split injection (0.8 min. hold) was applied with temperature at $220{ }^{\circ} \mathrm{C}$, helium as carrier gas at $6 \mathrm{ml} / \mathrm{min}$. flow rate. ECD and NPD temperatures were at $270{ }^{\circ} \mathrm{C}$ and $225{ }^{\circ} \mathrm{C}$, respectively. Column temperatures for cypermethrin resolution was at $170{ }^{\circ} \mathrm{C}$. According to these conditions, cypermethrin which contains a third asymmetric center, was resolved into an envelope of three peaks with retention times of 21.93, 22.66 and $23.34 \mathrm{~min}$.

For the assessment of the extraction efficiency of cypermethrin, triplicate fortified samples with $100 \mathrm{ng}$ of technical tested pesticides were made directly to urine and the extract of each of faeces, kidneys, spleen, liver and muscles samples of control animals. Reported levels of cypermethrin in the collected samples from control and treated animals had not been adjusted on the basis of percent recoveries. This was due to the very high percent of recovery.

Statistical significance between experimental and control values were calculated according to Student's "t" test as described by Fisher (1950) using SPSS 16.0 .

\section{RESULTS}

\section{Organ: body weight ratio}

Sheep in all groups survived to the end of the study. A significant increase in relative liver and spleen weights was observed in sheep treated with cypermethrin, and a dose-response relationship was observed (table 1). Weights of brain, heart kidneys and testis were not affected (data not shown).

Table 1: Mean body weight and relative organ weights of slaughtered male sheep after oral daily administration of Cypermethrin.

\begin{tabular}{lcccc}
\hline & Dose & Body weight & \multicolumn{2}{c}{ Relative weight } \\
\hline Pesticide & $(\mathrm{mg} / \mathrm{kg} / \mathrm{day})$ & $(\mathrm{kg})$ & \multicolumn{2}{c}{$(\mathrm{g} / \mathrm{g}) \times 10^{3}$} \\
\hline Corn oil (control) & $0.1(\mathrm{ml} / \mathrm{kg} / \mathrm{day})$ & $29.47 \pm 4.35$ & $13.54 \pm 0.83$ & $5.42 \pm 1.35$ \\
\hline \multirow{3}{*}{ Cypermethrin } & $\begin{array}{c}6 \\
(\mathrm{mg} / \mathrm{kg} / \mathrm{day})\end{array}$ & $29.20 \pm 3.86$ & $17.09 \pm 1.58^{*}$ & $6.98 \pm 2.11^{*}$ \\
\cline { 2 - 5 } & $\begin{array}{c}12 \\
(\mathrm{mg} / \mathrm{kg} / \mathrm{day})\end{array}$ & $30.40 \pm 2.89$ & $17.54 \pm 1.51^{*}$ & $8.99 \pm 2.55^{*}$ \\
\hline
\end{tabular}

Values represent the mean \pm SE of three animals.

* Within columns, significantly different from control $(\mathrm{P}<0.05)$.

\section{Liver and brain biochemistry}

The activities of liver AST, ALT, AIP, AcP, and LDH are shown in table (2). Liver AST and ALT activities in male sheep were significantly increased after treatment with cypermethrin $(6,12 \mathrm{mg} / \mathrm{kg}$ body weight, respectively).

Table 2: Enzymatic status of liver in male sheep after oral administration of Cypermethrin.

\begin{tabular}{lccc}
\hline & & \multicolumn{2}{c}{ Cypermethrin } \\
\cline { 2 - 3 } Parameters & Control & \multicolumn{2}{c}{ Doses (mg/kg/day) } \\
\cline { 2 - 4 } & & 6 & 12 \\
\hline AST (U/L) & $14.71 \pm 1.53$ & $21.2 \pm 1.88^{*}$ & $25.9 \pm 3.14^{*}$ \\
\hline ALT (U/L) & $3.02 \pm 0.25$ & $3.66 \pm 0.27^{*}$ & $4.24 \pm 0.43^{*}$ \\
\hline AlP (U/L) & $0.43 \pm 0.02$ & $0.44 \pm 0.03$ & $0.45 \pm 0.04$ \\
\hline AcP (U/L) & $1.96 \pm 0.08$ & $1.94 \pm 0.06$ & $1.98 \pm 0.07$ \\
\hline LDH (U/L) & $23.12 \pm 2.06$ & $16.3 \pm 1.14^{*}$ & $14.2 \pm 1.21^{*}$
\end{tabular}

Values represent the mean $\pm \mathrm{SE}$ of three animals.

(a) IU/g = International unit, the amount of the enzyme that under defined assay conditions will catalyze 1 mole of substrate per minute per gram liver tissue.

${ }^{*}$ Within rows significantly different from control $(\mathrm{P}<0.05)$. 
Table 3 shows the effect of oral administration of cypermethrin on the activities of brain enzymes. Cypermethrin at both doses did not show any significant change in AChE activity. Cypermethrin treated animals at both doses show a significant decrease in $\mathrm{Na}^{+}, \mathrm{K}^{+}$-ATPase and $\mathrm{Mg}^{++}$-ATPase activities as compared to control.

Table 3: Brain biochemical changes in male sheep after administration of Cypermethrin.

\begin{tabular}{lccc}
\hline Parameters $^{\text {(a) }}$ & Control & \multicolumn{2}{c}{ Cypermethrin } \\
\cline { 3 - 4 } & & \multicolumn{2}{c}{ Doses (mg/kg/day) } \\
\hline $\mathrm{AChE}^{\mathrm{a}}$ & $31.67 \pm 1.23$ & $30.58 \pm 1.12$ & $31.13 \pm 1.08$ \\
\hline $\mathrm{Na}^{+}, \mathrm{K}^{+}$-ATPase & $66.21 \pm 3.20$ & $47.51 \pm 2.83^{*}$ & $41.8 \pm 2.24^{*}$ \\
\hline $\mathrm{Mg}^{++}$-ATPase & $36.10 \pm 2.14$ & $22.71 \pm 1.78^{*}$ & $19.3 \pm 1.45^{*}$ \\
\hline
\end{tabular}

Values represent the mean \pm SE of three animals.

(a) Activity expressed in $\mu$ moles substrate hydrolysed/min./g tissue.

$\mathrm{b}$ Activity expressed in $\mu$ mole $\mathrm{Pi} / \mathrm{g}$ protein/min.

* Within rows significantly different from control $(\mathrm{P}<0.05)$.

\section{Residue analysis}

Residues of cypermethrin were below the detection levels $(50 \mathrm{pg} / \mu \mathrm{l})$ in all samples collected from control animals. Average recoveries of $100 \mathrm{ng}$ of cypermethrin from urine, feces, kidneys, spleen, liver and forequarter muscles of control sheep were ranged from 64 to $96 \%$, and the relative standard error for detected levels ranged between 2.34 and $5.49 \%$ (Table 4).

Table 4: Percent recovery of 100 ng of cypermethrin in feces, urine, kidney, spleen, liver and muscle of control sheep $($ mean $\pm \mathrm{SE})$.

\begin{tabular}{ccccccc}
\hline & Feces & Urine & Kidney & Spleen & Liver & Muscle \\
\cline { 2 - 6 } Recovery $\%$ & $79.54 \pm 2.37$ & $96.37 \pm 2.85$ & $90.2 \pm 2.34$ & $87.0 \pm 2.66$ & $89.6 \pm 2.68$ & $74.1 \pm 3.89$ \\
\hline
\end{tabular}

The results of cypermethrin residues in urine and feces during the experimental period are shown in table 5 . These results indicated that the residues of cypermethrin were detected in all urine and feces samples of treated animals.

Table 5: Residue levels in feces ( $\mathrm{ng} / \mathrm{g}$ ) and urine (ng/ml) during treatment of male sheep with pesticides (mean \pm SE of three animals).

\begin{tabular}{|c|c|c|c|c|c|c|c|c|c|}
\hline \multirow[t]{3}{*}{ Doses } & \multicolumn{9}{|c|}{ Cypermethrin Treatment (weeks) } \\
\hline & 1 & 2 & 3 & 4 & 5 & 6 & 7 & 8 & 9 \\
\hline & \multicolumn{9}{|c|}{ Feces } \\
\hline \multirow[t]{2}{*}{$6 \mathrm{mg} / \mathrm{kg} / \mathrm{day}$} & 11.31 & 15.92 & 16.0 & 14.43 & 31.79 & 53.49 & 52.31 & 54.62 & 50.37 \\
\hline & \pm 1.64 & \pm 0.45 & \pm 1.71 & \pm 1.78 & \pm 1.49 & \pm 2.90 & \pm 1.39 & \pm 5.30 & \pm 3.34 \\
\hline 12 & 14.59 & 17.65 & 28.09 & 23.67 & 51.09 & 64.73 & 66.03 & 63.51 & 69.35 \\
\hline \multirow[t]{2}{*}{$\mathrm{mg} / \mathrm{kg} / \mathrm{day}$} & \pm 0.67 & \pm 2.19 & \pm 0.89 & \pm 2.76 & \pm 4.34 & \pm 4.60 & \pm 4.54 & \pm 4.34 & \pm 2.47 \\
\hline & \multicolumn{9}{|c|}{ Urine } \\
\hline \multirow{2}{*}{$6 \mathrm{mg} / \mathrm{kg} / \mathrm{day}$} & 18.64 & 32.91 & 41.63 & 36.41 & 35.68 & 3.19 & 45.75 & 56.19 & 72.04 \\
\hline & \pm 1.81 & \pm 1.44 & \pm 1.88 & \pm 2.83 & \pm 3.03 & \pm 1.65 & \pm 3.43 & \pm 3.85 & \pm 3.66 \\
\hline \multirow[t]{2}{*}{$12 \mathrm{mg} / \mathrm{kg} /$ day } & 23.69 & 48.89 & 47.1 & 57.06 & 52.83 & 60.16 & 72.97 & 116.0 & 102.3 \\
\hline & \pm 0.36 & \pm 3.25 & \pm 2.89 & \pm 3.00 & \pm 4.60 & \pm 3.00 & \pm 5.09 & \pm 8.16 & \pm 6.89 \\
\hline
\end{tabular}


Results on the residues of cypermethrin in the tissues of kidneys, spleen, liver and forequarter muscles of treated animals after 63 days are presented in table 6 . The results indicated that cypermethrin was detected in all tissue samples of treated animals. The pesticide residues in tissues of control animals were under detection limits (50 $\mathrm{pg} / \mu \mathrm{l})$.

Table 6: Residual levels (ng/g) of cypermethrin in tissues of male sheep after treatment (mean \pm SE of three animals).

\begin{tabular}{lcc}
\hline Tissues & \multicolumn{3}{c}{ Cypermethrin Doses } \\
\cline { 2 - 3 } & 6 & 12 \\
\hline Kidney & $64.2 \pm 3.05$ & $156.1 \pm 3.97$ \\
\hline Spleen & $69.0 \pm 4.04$ & $148.5 \pm 2.98$ \\
\hline Liver & $12.2 \pm 0.20$ & $14.3 \pm 0.33$ \\
\hline Muscle & $62.4 \pm 3.03$ & $84.6 \pm 4.25$ \\
\hline
\end{tabular}

\section{DISCUSSION}

Cypermethrin, (type II synthetic pyrethroid), is being increasingly used as dips for treatment and control of ticks, lice and scab on sheep (Khan et al., 2012). The speedy insect killing properties of cypermethrin is believed to reduce its toxicity to mammalian tissues. However, it is fairly toxic when applied dermally or administered orally (Baselt, 2008; Aslam et al., 2010).

The results of the current study revealed significant dose-dependant increase in relative liver and spleen weights in sheep treated with cypermethrin. The significant liver enlargement after cypermethrin exposure indicated an increase in the functional load of the organ. These findings are in agreement with the results reported by Hend and Butterworth (1977) and US-EPA (1984) in rats treated with cypermethrin. An increase in spleen weight was observed in the present study for sheep being treated with cypermethrin.

With regard to hepatic toxicity, current results showed significant increase of hepatic AST and ALT activities in male sheep after treatment with cypermethrin. The elevation AST and ALT activities was dose dependent. On the other hand, hepatic tissue activity of LDH was significantly lower than those of the control in sheep treated with cypermethrin. Transaminases (AST and ALT) are important and critical enzymes in the biological processes. These enzymes are involved in the breakdown of amino acids into $\alpha$ keto acid which are routed for complete metabolism through the Kreb's cycle and electron transport chain. Consequently, they are considered as a specific indicator for liver damage (Harper et al., 1979). An increased AST activity was observed by Shakoori et al. (1988) in albino rats administrated cypermethrin. Shakoori et al. (1992) reported increased liver transaminases
(AST and ALT) activities after cyhalothrin administration in rabbits. The dosages of cypermethrin given for 63 days did not elicit significant changes in the liver phosphatases, as it is well known that phosphatases are responsible for transport mechanisms involving phosphates. The hepatic LDH activity indicates the switching over of anaerobic glycolysis to aerobic respiration. The decreased hepatic LDH activity may be due to the hepatocellular necrosis leading to leakage of the enzyme and/or enzyme inhibition. The results of this study showed a significant decrease in LDH activity of cypermethrin and dimethoate treated sheep. These results are in agreement with the results reported by Wang and Zhai (1988).

With regard to neural toxicity, brain did not show significant changes in the activity of acetylcholinesterase (AChE) in sheep treated with both doses cypermethrin compared with control. Brain ATPase is a key enzyme in cellular water balance and in osmoregulation in the whole animal. Cypermethrin treated animals at both doses show a significant decreases in brain $\mathrm{Na}^{+}, \mathrm{K}^{+}$-ATPase and $\mathrm{Mg}^{++}$-ATPase activities. Several classes of pesticides were known to inhibit ATPases activities (Koch, 1969; Cutkomp et al., 1976). Several opinions were expressed for such an inhibition in the ATPase activity in the cellular system. Inhibition indicates an overall disruption in the energy metabolism. $\mathrm{Na}^{+}, \mathrm{K}^{+}$-ATPase enzyme is associated with lipoprotein in the form of a complex (Nakao et al., 1974). If a lipophilic compound were to come in contact with this lipoprotein and partitioning into the lipid fraction occurred, an allosteric change could occur which could alter the activity of the enzyme. Kinter et al. (1972) hypothized that lipophilic pesticides exert their biologic effects on ATPase system by interacting with the phospholipidactivating component of the enzyme complex. The lipophilic partitioning of ATPase enzyme by 
cypermethrin may produce allosteric change resulting in decreased ATPase activity. A decrease in $\mathrm{Mg}^{++}$. ATPase and $\mathrm{Na}^{+}, \mathrm{K}^{+}$-ATPase activities in the rat was reported by La Rocca and Carlson (1979).

Residues of pesticides were below the detection levels $(50 \mathrm{pg} / \mu \mathrm{l}$ of cypermethrin) in all samples collected from control animals. Average recoveries of $100 \mathrm{ng}$ of cypermethrin from urine, feces, kidneys, spleen, liver and forequarter muscles of control sheep were ranged from 64 to $96 \%$, and the relative standard error for detected levels of pesticides ranged between 2.34 and $5.49 \%$ (table 4).

The present study showed that residues of cypermethrin were detected in all urine and feces samples of treated animals. This indicated that the main routes for cypermethrin excretion from the body were through both urine and feces. Croucher et al. (1985) found that the major routes for elimination of oral administration of cypermethrin in cows were via both urine (approximately $50 \%$ ) and feces (approximately 40\%). The elimination pattern in sheep, given one oral dose of cypermethrin (3.9 $\mathrm{mg} / \mathrm{kg}$ body weight), showed that $41 \%$ of the administered dose excreted in the urine and $20 \%$ was eliminated in feces (Crawford and Hutson, 1977). The detected levels of pesticides were dosedependent. On the other hand, the results of cypermethrin residues in the tissues of treated animals revealed the detection of cypermethrin in all tissue samples of treated animals. Moreover, the present results showed that the residue levels of cypermethrin were in the following decreasing order: kidneys $>$ spleen $>$ muscles $>$ liver at levels ranging from 12.2 to $156.1 \mathrm{ng} / \mathrm{g}$ for cypermethrin. Croucher et al. (1985) found that the residues of cypermethrin were detected in milk, blood, liver, kidneys and subcutaneous and renal fat of cows. Crawford and Hutson (1977) also reported that the residues of cypermethrin were detected in muscle, liver, kidneys and renal fat of sheep. Cattle sprayed once with $0.1 \%$ and $0.2 \%$ of cypermethrin showed that the residues in muscle, liver, and kidneys were $\leq 0.005 \mathrm{mg} / \mathrm{kg}$ in tissues and $<0.01 \mathrm{mg} / \mathrm{kg}$ in fat. In cattle treated twice with cypermethrin, fat samples contained residues ranging from 0.01 to $0.05 \mathrm{mg} / \mathrm{kg}$ tissue (Bosio, 1979).

In conclusion, the obtained results indicate that cypermethrin produces moderate toxic effects in different animal systems including hepatic and neural functions. Concerning the record of cypermethrin residues in feces and urine as well as other body tissues and organs, great attention should be taken during its field application to avoid the possible significant adverse effects in non-target species including humans and other livestock animals.

\section{REFERENCES}

Abd-Alla, E.A.M.; Nassar, A.M.; Neamat-Allah, A.A. and Aly, S.E. (2002): Prevalence of pesticide residues in fish, cheese and human milk. Assiut Vet. Med. J., 47: 110-124

Abdul Mujeeb, Kh. and Shakoori, A. (2007): Toxicity of Synthetic Pyrethroid, Fury, Against Different Developmental Stages of Three Strains of Tribolium castaneum (Herbst). Pakistan J. Zool., 39(6): 361-366.

A.O.A.C. (1984): "Official Methods of Analysis". 14th Ed. Association of Official Agricultural Chemists, Arlington, Virginia 22209 U.S.A.

Abou Zeid, M.M.; El-Barouty, G.; Abdel-Reheim, E.; Blancato, J.; Dary, C.; El-Sebae, A.H. and Saleh, M. A. (1993): Malathion disposition in dermally and orally treated rats and its impact on the blood serum acetylcholine esterase and protein profile. J. Environ. Sci. Health, part B, 28: 413-430.

Ahmad, L.; Khan, A. and Khan, M.Z. (2012): Pyrethroid-inducedreproductive toxicopathology in non-target species. Pakistan Vet. J., 32: 1-9.

Aslam, F.; Khan, A.; Khan, M.Z.; Sharaf, S.; Gul, S.T. and Saleemi, M.K. (2010): Toxicopathological changes induced by cypermethrin in broiler chicks: Their attenuation with Vitamin E and selenium. Exp. Toxicol. Pathol., 62: 441-450.

Baselt, R. (2008): Disposition of Toxic Drugs and Chemicals in Man. 8th edition, Biomedical Publications, Foster City, CA.

Bergmeyer, H.V. (1963): Method of enzymatic analysis. Academic Press, N. Y., pp 779-787.

Bessey, O.A.; Lowry, O.H. and Brock, M.J. (1964): A method for the rapid determination of alkaline phosphatase with $5 \mathrm{cc}$ serum. J. Biol. Chem., 164: 321-329.

Bosio, P.G. (1979): BEGR. 79.117 Residues of Barricade (cypermethrin) in cattle from Australia Overspray Experiments. Berre, France, Shell Chimie.

Braun, H.E. and Stanek, J. (1982): Application of the AOAC multi-residue method to determination of synthetic pyrethroid residues in celery and animal products. J. Assoc. Off. Anal. Chem., 65: 685-689.

Cabaud, P.C. and Wroblewski, F. (1958): Calorimetric measurement of lactate dehydrogenase activity of body fluids. J. Clin. Pathol., 30: 234-236.

Crawford, M.J. and Hutson, D.H. (1977): The elimination and retention of W143467 when administered dermally or orally to sheep. Sittingbourne, Shell Research (TLGR. 0098.77). 
Croucher, A.; Hutson, D.H. and Stoydin, G. (1985): Excretion and residues of the pyrethroid insecticide cypermethrin in lactating cows. Pestic. Sci., 16: 287-30.

Cutkomp, L.K.; Desaiah, D.; Cheng, E.Y.; Ves, E.V. and Koch, R.B. (1976): The in vivo sensitivity of ATPase activity in cockroaches. Pestic. Biochem. Physiol., 4: 232-238.

Cutkomp, L.K.; Yap, H.H.; Cheng, E.Y. and Koch, R.B. (1971): ATPase activity in fish tissue homogenates and inhibitory effects of DDT and related compounds. Chem. Biol. Interactions, 3: 439-447.

Dunnick, J.K.; Cupta, B.N.; Harris, M.W. and Lamb, J.C. (1984): Reproductive toxicity of dimethyl methyl phosphate (DMMP) in the male Fischer 344 rate. Toxicol. Appl. Pharmacol., 72: 379-387.

El-Sebae, A.H. (1990): Fate and undesirable effects of pesticides in Egypt. in "Toxicology and Climate” Eds. Bourdeau P., J A, Hains, W. Klein and C. R. Krishna Muri, New York: John Wiley and Sons Ltd, pp. 349-71.

Ellman, G.L.; Gourtney, K.D.; Andress, V.J.R. and Featherstone, R.M. (1961): A new rapid calorimetric determination of acetylcholinestrase activity. Biochem. Pharmacol., 7: 88-96.

Fisher, R.A. (1950): Statistical Methods for Research Workers. 11 th Ed., Oliver and Boyd Ltd, Edinburgh U K.

Fiske, C.Y. and Subbarow, Y.J. (1925): The colorimetric determination of phosphorus. Biol. Chem., 67: 376-400.

Hardeng, F.; Baalsrud, K.J. and Overnes, G. (1992): Controlling tick infestations and diseases in sheep by pour-on formulations of synthetic pyrethroids. A field study. Vet. Res. Commun., 16: 429-436.

Harper, H.A.; Rodwell, V.W. and Mayers, P.A. (1979): Review of Physiological Chemistry. Middle East Edition.

Hend, R.W. and Butterworth, S.T.G. (1977): Toxicity studies on the insecticide WL 43481: a fiveweek feeding study in rats, Sittinbourne, Shell Research (Unpublished report).

Khan, A.; Ahmad, L. and Khan, M.Z. (2012): Hemato-biochemical changes induced by pyrethroid insecticides in avian, fish and mammalian species. Int. J. Agric. Biol., 14: 834-842.

Kinter, W.B.; Merkens, L.S.; Janiki, R.H. and Guarino, A.M. (1972): Studies on the mechanism of toxicity of DDT and PCBs: Disruption of osmorgulation in marine fish. Environ. Hlth. Pers., 8:169-173.

Koch, R.B. (1969): Chlorinated hydrocarbon insecticides: Inhibition of rabbit brain ATPase activities. J. Neurochem., 16: 269-271.
La Rocca, P.T. and Carlson, G.P. (1979): The effect of polychlorinated biphenyl's on adenosine triphosphatase activity. Toxic. Appl. Pharmacol., 48: 185-192.

Lowry, O.H.; Rosebrough, N.J.; Farr, A.L. and Randall, R.J. (1951): Protein measurement with the Folin Phenol Reagent. J. Biol. Chem., 193: 265-275.

Luty, S.; Lutuszyiska, J.; Halliop, J.; Tochman, A.; Obuchowska, D.; Przylepa, E. and Korezak, E. (1998): Toxicity of dermally applied alphacypermethrin in rats. Ann. Agric. Environ. Med., 5: 109-115.

Moore, A. and Waring, C.P. (2001): The effects of a synthetic pyrethroid pesticide on some aspects of reproduction in Atlantic salmon (Salmo salar L.). Aquatic Toxicology 52: 1-12.

Nakao, M.; Nakao, T.; Hara, Y.; Nagai, F. and Ygasaki, S. (1974): Purification and properties of $\mathrm{Na}^{+}-\mathrm{K}^{+}$ATPase from pig brain. N.Y.Ann. Acad. Sci., 242: 24-35.

N.R.C. (National Research council) (1985): Nutrient Requirements of Sheep, Sixth Revised Edition. National Academy Press Washington. D.C.

Reitman, S. and Frankel, S.A. (1957): Colorimetric method for determination of serum glutamic oxaloacetic and glutamic pyruvic transaminases. Am. J. Clin. Pathol., 28: 56-63.

Shakoori, A.R.; Ali, S.S. and Saleem, M.A. (1988): Effects of six months' feeding of cypermethrin on the blood and liver of albino rats. J. Biochem. Toxicol., 3: 59-71.

Shakoori, A.R.; Aslam, M.; Sabir, M. and Ali, S.S. (1992): Effect of prolonged administration of insecticide (cyhalothrin/karate) on the blood and liver of rabbits. Folia Biol. Krakw., 40: 91-99.

Sharaf, S.; Khan, A.; Khan, M.Z.; Aslam, F.; Saleemi, M.K. and Mahmood, F. ( 2010): Clinico-hematological and micronuclear changes induced by cypermethrin in broiler chicks: Their attenuation with vitamin $\mathrm{E}$ and selenium. Exp. Toxicol. Pathol., 62: 333-341.

US EPA. (1984): Cypermethrin: tolerances for residues in or on raw agricultural commodities: final rule. Part III. Fed. Reg., 49(117): 24865-24872.

Wang, $X$. and Zhai, W. (1988): Cellular and biochemical factors in bronchoalveolar lavage fluids of rats exposed to fenvalerate. Zhongguo Yaolixue Yu Dulixue Zoghi., 2: 271-276.

Yousef, M.I.; Ibrahim, H.Z; Yacuot, M.H.M. and Hassan, A.A. (1998): Effects of cypermethrin and dimethoate on some physiological and biochemical parameters in Barki sheep. Egyptian J. Nutr. Feed, 1: 41-52. 


\section{دراسة تأثير سمية مركب السيبرميثرين على الكبد والأعصاب ومتبقياتها في الانسجة في ذكور الاغنام الصوماليه (بربرا بلاكهيا )}

\section{عادل جلال الشبيسي ، غاده /حمد محدل ابو العلا}

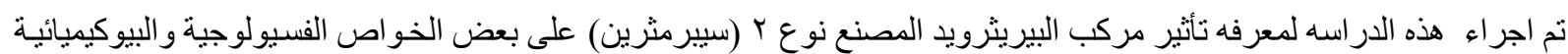

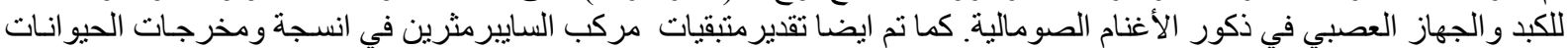

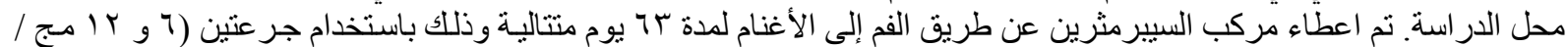

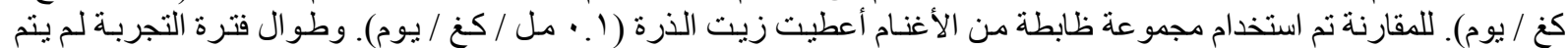

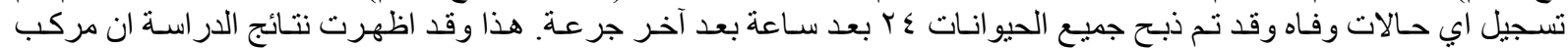

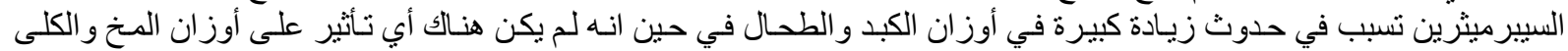

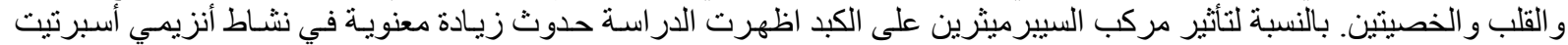

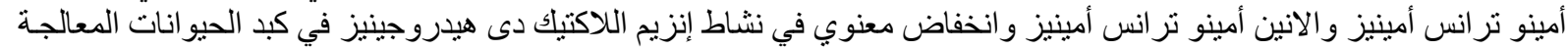

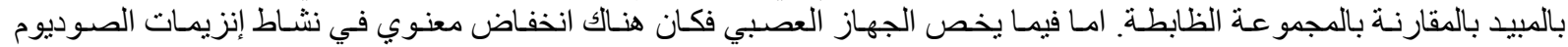

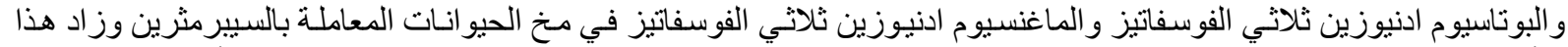

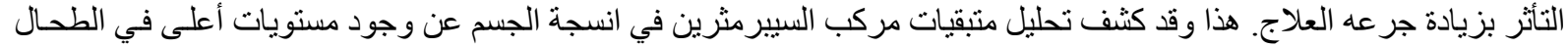

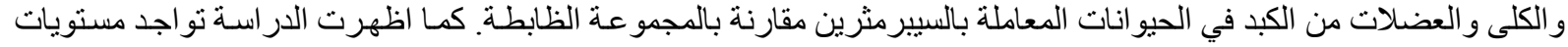

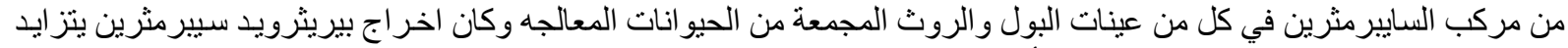

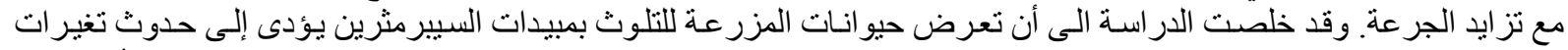

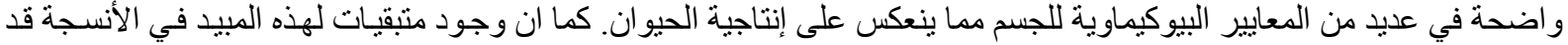

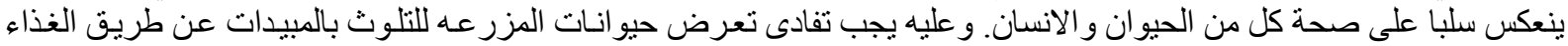

